\title{
PEMBERDAYAAN SISWA SMK MELALUI PELATIHAN PENERAPAN ALAT DETEKSI BANJIR BERBASIS IoT DI KAB. BULUKUMBA MELALUI PROGRAM KKN PPM
}

\author{
Yasser A. Djawad ${ }^{1}$, Hendra Jaya ${ }^{2}$,Saliruddin ${ }^{3}$ Supriadi $^{4}$ \\ 1,2 Jurusan Pendidikan Teknik Elektronika, Fakultas Teknik UNM \\ E-Mail: yasserpdb@gmail.com, hendra.jaya@unm.ac.id, , saliruddin@unm.ac.id, \\ supriadi6722@unm.ac.id
}

\begin{abstract}
Abstrak
Target luaran yang akan dicapai adalah Meningkatkan kepedulian dan empati mahasiswa kepada permasalahan masyarakat yang berada di Desa Salemba, Kecamatan Ujung Loe, Kabupaten Bulukumba khususnya siswa SMKN 3 Bulukumba, sehingga terjadi perubahan perilaku mahasiswa dan siswa SMKN 3 Bulukumba dalam menyikapi pentingnya pelatihan sikap, keterampilan, dan strategi adaptasi dalam menghadapi bencana, yang nantinya dapat memberdayakan masyarakat secara pengetahuan, sehingga masyarakat justru akan menjadi lebih paham dan 2. terampil sigap dalam menghadapi bencana; 3. Mengatasi permasalahan yang dihadapi masyarakat di sekitar desa di Kecamatan Ujung Loe, Kabupaten Bulukumba melalui pelatihan sikap, keterampilan, dan strategi adaptasi dalam menghadapi bencana; 4. Mahasiswa memiliki kemampuan menyusun program dan mengimplementasikan program KKN-PPM dengan perencanaan yang terinci selama satu bulan; 5. Mahasiswa dapat berkolaborasi dengan Siswa SMKN 3 Bulukumba melalui program pelatihan. Berdasarkan capaian hasil pelaksanaan pelatihan dan sosialisasi mitigasi bencana di SMKN 3 Bulukumba, maka dapat disimpulkan sebagai berikut:1) Meningkatnya keterampilan dan pengetahuan siswa SMKN 3 Bulukumba terhadap pembuatan dan aplikasi teknologi informasi Deteksi banjir berbasis IoT; 2) meningkatnya kesadaran siswa SMKN 3 Bulukumba akan menjaga lingkungan dari bahaya bencana banjir; 3) meningkatnya pengetahuan siswa SMKN 3 Bulukumba tentang sikap tanggap bencana.
\end{abstract}

Kata Kunci: Mitigasi Bencana, Teknologi Informasi, SMK.

\section{Abstract}

The output target to be achieved is to increase the awareness and empathy of students to the problems of the community in Salemba Village, Ujung Loe District, Bulukumba Regency especially the students of SMKN 3 Bulukumba, so that there is a change in the behavior of students and students of SMK 3 Bulukumba in addressing the importance of attitude, skills training, and adaptation strategies in dealing with disasters, which in turn can empower the community in knowledge, so that the community will actually become more understanding and 2. skillful in dealing with disasters; 3 . Overcoming the problems faced by communities around the village in Ujung Loe District, Bulukumba Regency through training in attitudes, skills and adaptation strategies in dealing with disasters; 4. Students have the ability to compile programs and implement KKN-PPM programs with detailed planning for one month; 5. Students can collaborate with Bulukumba 3 SMKN Students through a training program. Based on the results of the implementation of the training and dissemination of disaster mitigation at SMKN 3 Bulukumba, it can be concluded as follows: 1) Increased skills and knowledge of SMKN 3 Bulukumba students towards the creation and application of IoT-based flood detection information technology; 2) increasing awareness of SMK 3 Bulukumba students will protect the environment from the dangers of flooding; 3) increasing knowledge of SMK 3 Bulukumba students about disaster response attitudes.

Keywords: Disaster Mitigation, Information Technology, Vocational School. 


\section{PENDAHULUAN}

Ujung Loe adalah sebuah kecamatan di kabupaten Bulukumba, Sulawesi Selatan, Indonesia.kecamatan Ujung Loe merupakan salah satu dari 10 kecamatan di Kabupaten Bulukumba. Di kecamatan ini terdapat 12 desa/kelurahan, yaitu Balleanging, Balong, Bijawang, Dannuang, Garanta, Lonrong, Manjalling, Manyampa, Padang loang, Salemba, Seppang, dan Tamatto. Masih banyak perumahan yang merupakan rumah kayu yang didirikan di kecamatan ini.

Luas wilayah Desa Salemba adalah 556 Ha yang terdiri dari 45 Ha rupa tambak, $40 \mathrm{Ha}$ rupa lahan pertanian dan sisanya pemukiman. Sebagiamana wilayah tropis, Desa Salemba mengalami musim kemarau dan musim penghujan dalam tiap tahunnya. Secara visualisasi, wilayah administratif dapat dilihat peta wilayah Desa Salemba sebagai berikut :

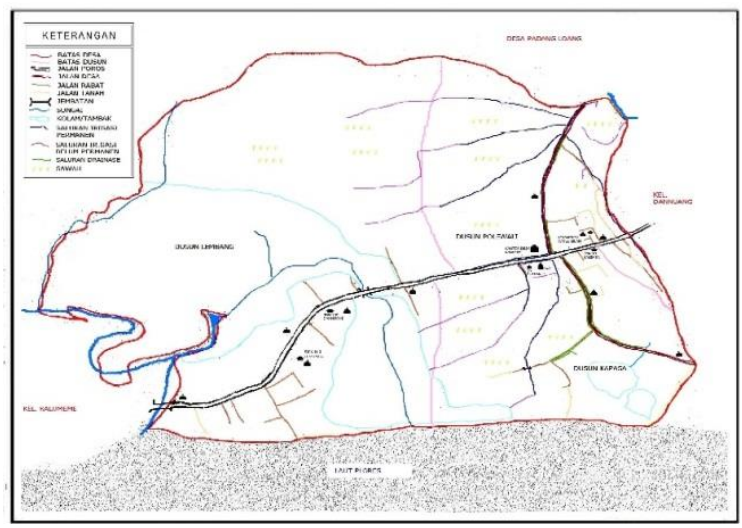

Gambar 1.1. Peta wilayah Desa Salemba

Desa Salemba marupakan salah satu Desa yang cukup rawan terhadap benjir. Saat memasuki musim penghujan kemarin, hujan yang mengguyur kabupaten Bulukumba cukup deras yang membuat arus sungai di Desa Salemba, kecamatan Ujung Loe meluap. Akibatnya, salah satu dusun di desa Salemba kecamatan Ujung Loe terendam banjir setinggi 1,5 Meter. Berdasarkan data yang dihimpun, hingga malam hari, puluhan warga di daerah itu masih terendam banjir. Bahkan akses dari Bulukumba-Bira terputus karena derasnya arus banjir.
Pada wilayah ini terdapat sekolah kejuruan yakni SMKN 3 Bulukumba. Pemberdayaan kegiatan difokuskan pada siswa SMK dengan alasan Pendidikan SMK setara kedudukannya dengan pendidikan lainnya, seperti Sekolah Menengah Atas (SMK) dan Madrasah Aliyah (MA). Tujuan umum pendidikan SMK adalah untuk mendukung pengembangan dunia usaha dan dunia industri baru dan memperbaiki mutu industri yang sudah ada. Di samping itu, SMK juga mempunyai tujuan khusus untuk mencetak tenaga-tenaga yang terampil dan profesional di bidangnya, serta siap berperan aktif dalam pembangunan nasional. Pendidikan SMK memiliki beberapa kelebihan, yaitu: (1) keterampilan/keahlian dalam pendidikan terkontrol dengan pasti, (2) lulusan memiliki kompetensi dan kompetisi sesuai tuntutan dunia usaha dan dunia industri, dan (3) lulusan masih bisa melanjutkan studi ke jenjang yang lebih tinggi, baik pada jalur profesional maupun akademik.

SMK dianggap sebagai sekolah yang memiliki peserta didik yang memiliki keterampilan dalam bidang teknologi Informasi. Untuk itu dalam kegiatan pemberdayaan dibuat konsep perencanaan pelatihan sikap guna menumbuhkembangkan rasa keperdulian siswa SMK terhadap pentingnya menjaga lingkungan. Dengan demikian dapat meningkatkan kesadaran siswa dan memperoleh lingkungan yang aman terhadap bahaya bencana banjir. Beberapa kegiatan yang berkaitan pemberdayaan diantaranya adalah sebagai berikut:

1. Menerapkan model pelatihan alat detektor bencana banjir berbasis IoT (Internet of Things) dalam meningkatkan pengetahuan masyarakat terhadap teknologi informasi khusunya dalam penanganan bahaya bencana banjir.

2. Memberikan pembinaan Siswa SMK melalui sosialisasi dan pendekatan agar tercapainya tujuan yang diinginkan.

3. Model pelatihan yang diterapkan kepada siswa SMK dilakukan dengan 
meningkatkan kompetensi pengetahuan teknologi informasi berdasarkan permasalahan.

4. Peningkatan pengetahuan teknologi informasi dan sikap terhadap bencana banjir sehingga dapat mengurangi resiko bahaya bencana banjir terhadap masyarakat desa Salemba.

Pelaksanaan KKN-PPM dengan tema
"pemberdayaan masyarakat melalui
pengurangan resiko bencana berbasis teknologi
informasi untuk pembudayaan sikap,
keterampilan, dan strategi adaptasi dalam
menghadapi bencana di daerah pesisir pantai
kab. Bulukumba" dalam jangka panjang
diharapkan:

1. Terjadi peningkatan pemahaman dan kesadaran siswa SMK dan mahasiswa akan pentingnya pengetahuan teknologi informasi dalam menumbuhkembangkan kesadaran masyarakat akan pentingnya menjaga lingkungan dari bahaya bencana banjir.

2. Pihak Lembaga Pengabdian kepada Masyarakat UNM dapat menjadikan kegiatan ini sebagai percontohan untuk daerah lain dengan tema yang berbeda dan dengan mitra yang lebih banyak seperti melibatkan industri yang berada dalam lingkup lokasi pelaksanaan $\mathrm{KKN}$ PPM.

3. Mahasiswa dan dosen dapat memperoleh inspirasi penelitian dalam berbagai aspek teknologi, sosial, sains, ekonomi, budaya, dan lingkungan.

\section{METODE PELAKSANAAN}

\section{A. Persiapan dan Pembekalan}

Persiapan dan pembekalan mahasiswa calon peserta KKN-PPM ini meliputi kegiatan:

1. Persuratan resmi oleh LPM ke beberapa jurusan (Teknik Elektronika, Teknik Mesin, Teknik Otomotif, Pendidikan Teknologi Pertanian,
Biologi, Fisika, Ekonomi, dan PKK) untuk rekruitmen mahasiswa peserta KKN-PPM;

2. Mahasiswa mendaftar ke satgas $\mathrm{KKN}$ UNM untuk menyelesaikan administrasi dan perlengkapan.

3. Persuratan resmi oleh LPM ke Pemkab Bulukumba, kecamatan Ujung Loe, desa Salemba propinsi Sulawesi Selatan dan Laboratorium Teknik Elektronika;

4. Penyiapan bahan untuk pembekalan dan persuratan resmi ke narasumber yang relevan dengan ilmunya;

5. Pelaksanaan pembekalan mahasiswa calon peserta KKN-PPM. Materi pembekalan mencakup: (i) Hakekat KKN-PPM; (ii) Softskill (diantaranya kepemimpinan, manajemen konflik, teknik berkomunikasi yang efektif); (iii) Wawasan kebangsaan; (iv) Profil Desa Salemba kecamatan Ujung Loe kabupaten Bulukumba; (v) Materi menyangkut tema pokok. Nara sumber untuk setiap materi adalah dari DPL sesuai bidang ilmunya, para ahli dan yang berkompeten di bidangnya.

6. Penyiapan bahan-bahan yang diperlukan dilokasi, seperti format laporan individu, laporan unit dan subunit, absensi, materi pokok tema, dan dokumentasi.

7. Jadwal pembekalan kegiatan KKNPPM ini selama 3 hari (dimulai jam 7.30 sampai jam 17.30) bertempat di ruang pertemuan LPM UNM Jln. Andi Pangerang Pettarani Makassar.

\section{B. Pelaksanaan}

Langkah-langkah yang akan ditempuh pada pelaksanaan KKN-PPM ini dapat dikemukakan sebagai berikut:

1. Pemberangkatan ke lokasi KKN, desa Salemba, kecamatan Ujung Loe.

2. Sosialisasi mahasiswa ke SMK di kecamatan ujungloe kabupaten Bulukumba tentang tema KKN-PPM 
dan untuk memperoleh masukan dan informasi tambahan program pendukung.

3. Penyusunan Pelatihan . Dalam hal ini setiap mahasiswa diwajibkan memiliki 5 program pokok (70 \% untuk program pokok tema, $30 \%$ program pendukung) dengan total waktu kerja efektif $=144$ jam per mahasiswa.

4. Seminar awal untuk penyempurnaan program pokok tema (Pelatihan Mitigasi Bencana berbasis Teknologi Informasi) dan penyusunan program bantu yang diikuti oleh pemerintah, tokoh masyarakat, dan lembaga mitra.

5. Pelaksanaan program Pelatihan siswa SMK melalui pelatihan penerapan alat deteksi banjir berbasis iot dengan metode ceramah, diskusi, praktek lapangan dan pembuatan alat.

6. Seminar program dilaksanakan setelah 1 minggu mahasiswa berada di lokasi guna memperbaiki program yang telah dilaksanakan dan penyiapan program berikutnya.

7. Penyusunan laporan pada minggu terakhir.

8. Seminar akhir program untuk mengevaluasi keterlaksanaan program dan membuat draft perencanaan program KKN-PPM berikutnya.

9. Penarikan peserta dari lokasi setelah berlangsung selama 1 bulan.

10. Perhitungan volume pekerjaan. Jumlah mahasiswa yang diterjunkan dalam KKNPPM, $\mathrm{n}=22$, sedangkan Jam Kerja Efektif Mahasiswa (JKEM), $\mathrm{y}=144$ jam selama 1 bulan $=30$ hari, maka volume total pekerjaan adalah $\mathrm{nxy}=22 \times 144$ jam $=3168$ jam. Selebihnya dapat digunakan untuk program kerja bantu.

Tempat pelaksanaan program KKN-PPM ini adalah di Kabupaten Bulkumba, desa Salemba berada di Ujung Loe.
Tabel 6. Lokasi Pelaksanaan KKN-PPM

\begin{tabular}{|l|l|c|}
\hline \multicolumn{1}{|c|}{ Desa } & Kecamatan & \multicolumn{1}{c|}{ Kabupaten } \\
\hline $\begin{array}{l}\text { SMKN 3 } \\
\text { Bulukumba }\end{array}$ & Ujung Loe & Bulukumba \\
\hline
\end{tabular}

\section{Rencana Keberlanjutan Program}

Perencanaan jangka panjang adalah Peningkatan pengetahuan siswa SMKN 3 Bulukumba dalam mengembangkan keterampilan dan pengetahuan teknologi informasi berbasis IoT. Lembaga mitra yang terlibat adalah kelompok laboratorium teknik Elektronika FT-UNM dan pemerintah kabupaten Bulukumba. Keterlibatan Siswa SMKN 3 Bulukumba sebagai sasaran antara yang strategis terus melakukan pengimbasan kepada SMK lainnya.

\section{Monitoring dan Evaluasi Program}

Monitoring dilaksanakan selama pelaksanaan program KKN-PPM oleh Penanggung jawab tema dan DPL (Dosen Pembimbing Lapangan). Dilakukan minimal satu kali seminggu dengan memeriksa laporan rencana kegiatan di setiap unit dan subunit, kartu kontrol setiap mahasiswa dan memberi paraf pada kartu kontrol tersebut. Evaluasi keterlaksanaan program dilakukan 3 kali yaitu pada awal, pertengahan, dan akhir pelaksanaan program. Metode evaluasi mencakup lisan dan tertulis. Tertulis dalam bentuk posttest tentang materi pembelakalan secara umum dan materi pokok tema KKNPPM. Selain itu dilakukan pula evaluasi proses yang mencakup proses pelaksanaan dan keberhasilan pelaksanaan program pada setiap unit dengan mencocokkan laporan rencana dan laporan hasil.

\section{HASIL PELAKSANAAN KEGIATAN KKN-PPM}

Adapun rekapitulasi capaian pelaksanaan program kerja KKN- PPM UNM 2019 di Desa Salemba, Kecamatan Ujung Loe, Kabupaten Bulukumba dapat dilihat pada Tabel berikut ini. 
Tabel 1. Rekapitulasi Capaian Pelaksanaan program kerja Pelatihan Penerapan Alat Deteksi Banjir Berbasis IoT pada SMKN 3 Bulukumba

\begin{tabular}{|l|l|l|l|c|}
\hline \multicolumn{1}{|c|}{ Nama Kegiatan } & $\begin{array}{l}\text { Waktu } \\
\text { Pelaksanaan }\end{array}$ & Jumlah Peserta & \multicolumn{1}{|c|}{$\begin{array}{c}\text { Tempat } \\
\text { Pelaksanaan }\end{array}$} & $\begin{array}{c}\text { Capaian } \\
\text { (\%) }\end{array}$ \\
\hline Program kerja Pokok: & \multicolumn{3}{|c|}{} \\
\hline $\begin{array}{l}\text { a. } \\
\text { Pelatihan dan } \\
\text { penerapan alat } \\
\text { deteksi banjir } \\
\text { berbasis IoT untuk } \\
\text { detektor bencana } \\
\text { banjir }\end{array}$ & $\begin{array}{l}\text { Rabu, Tanggal 17 } \\
\text { Juli 2019 }\end{array}$ & 40 orang & $\begin{array}{l}\text { SMKN 3 } \\
\text { Bulukumba }\end{array}$ & $100 \%$ \\
\hline $\begin{array}{l}\text { b. } \\
\text { Sosialisasi tentang } \\
\text { mitigasi bencana }\end{array}$ & 02 Agustus 2019 & 40 orang & $>\begin{array}{l}\text { SMKN 3 } \\
\text { Bulukumba }\end{array}$ & $100 \%$ \\
\hline
\end{tabular}

1. Faktor Pendukung dan Penghambat

a) Faktor Pendukung

Adapun faktor pendukung pelaksanaan program, antara lain: (1) adanya dukungan dari pihak sekolah yang cukup baik. (2) penyediaan fasilitas tempat oleh pihak Sekolah dalam pelaksanaan proker. (3) kerjasama yang baik antara anggota KKN-PPM UNM 2019

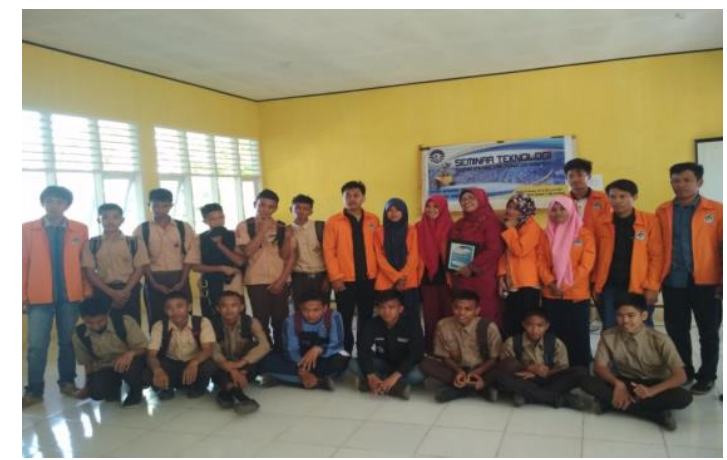

(a)

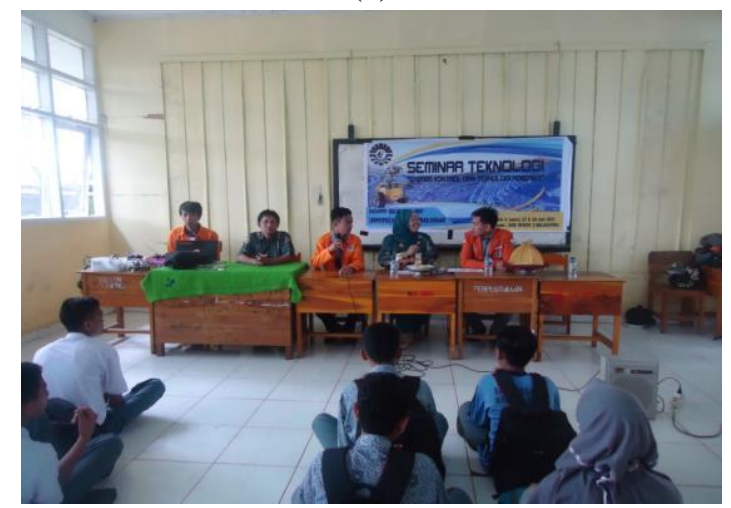

(b)

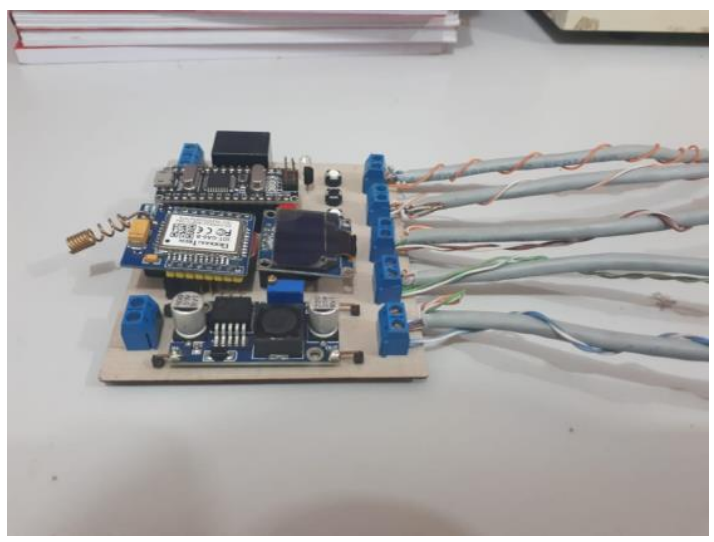

(c)

Gambar 2. (a) foto bersama dengan guru dan Siswa SMKN 3 Bulukumba; (b) Seminar

Teknologi Penyuluhan Bencana Dan Sekaligus Pelatihan Penerapan Alat Deteksi Banjir Berbasis IoT; (c) Alata Deteksi Banjir berbasis IoT

\section{b) Faktor Penghambat}

Adapun faktor penghambat pelaksanaan program, antara lain: (1) terbatasnya alat transportasi yang dimiliki oleh anggota KKN-PPM UNM 2019 sehingga agak sulit untuk melakukan koordinasi.

\section{Penilian Keberhasilan Pelatihan}

Pelaksanaan kegiatan pelatihan ini memberikan kontribusi positif kepada Siswa SMKN 3 Bulukumba hal ini ditandai, dimana kegiatan secara umum berjalan dengan lancar. Tingkat keberhasilan pelatihan didasarkan pada beberapa aspek 
indikator penilaian yang dilakukan yang

diperlihatkan melalui Tabel 1 dibawah ini

Tabel 2. Aspek penilaian keberhasilan pelatihan Siswa SMKN 3 Bulukumba

\begin{tabular}{|l|c|c|c|c|c|c|}
\hline ASPEK PENILAIAN & Tinggi & \% & sedang & \% & Rendah & \% \\
\hline $\begin{array}{l}\text { Pemahaman Siswa SMKN 3 } \\
\text { Bulukumba dalam menerima materi }\end{array}$ & $\mathbf{3 0}$ & 75 & $\mathbf{8}$ & 20 & $\mathbf{2}$ & 5 \\
\hline $\begin{array}{l}\text { Partisipasi Siswa SMKN 3 } \\
\text { Bulukumba dalam pelatihan }\end{array}$ & $\mathbf{3 4}$ & 85 & $\mathbf{6}$ & 15 & $\mathbf{0}$ & 0 \\
\hline $\begin{array}{l}\text { Siswa SMKN 3 Bulukumba } \\
\text { familiar dengan Metode yg } \\
\text { diberikan }\end{array}$ & $\mathbf{2 6}$ & 65 & $\mathbf{4}$ & 10 & $\mathbf{1 0}$ & 25 \\
\hline $\begin{array}{l}\text { Siswa SMKN 3 Bulukumba mampu } \\
\text { menerapkan Aplikasi Alat Deteksi } \\
\text { Banjir berbasis IoT }\end{array}$ & $\mathbf{2 5}$ & 62,5 & $\mathbf{1 0}$ & 25 & $\mathbf{5}$ & 12,5 \\
\hline $\begin{array}{l}\text { Keberhasilan guru dalam } \\
\text { menerapkan Aplikasi Alat Deteksi } \\
\text { Banjir berbasis IoT }\end{array}$ & $\mathbf{2 4}$ & 60 & $\mathbf{1 2}$ & 30 & $\mathbf{4}$ & 10 \\
\hline
\end{tabular}

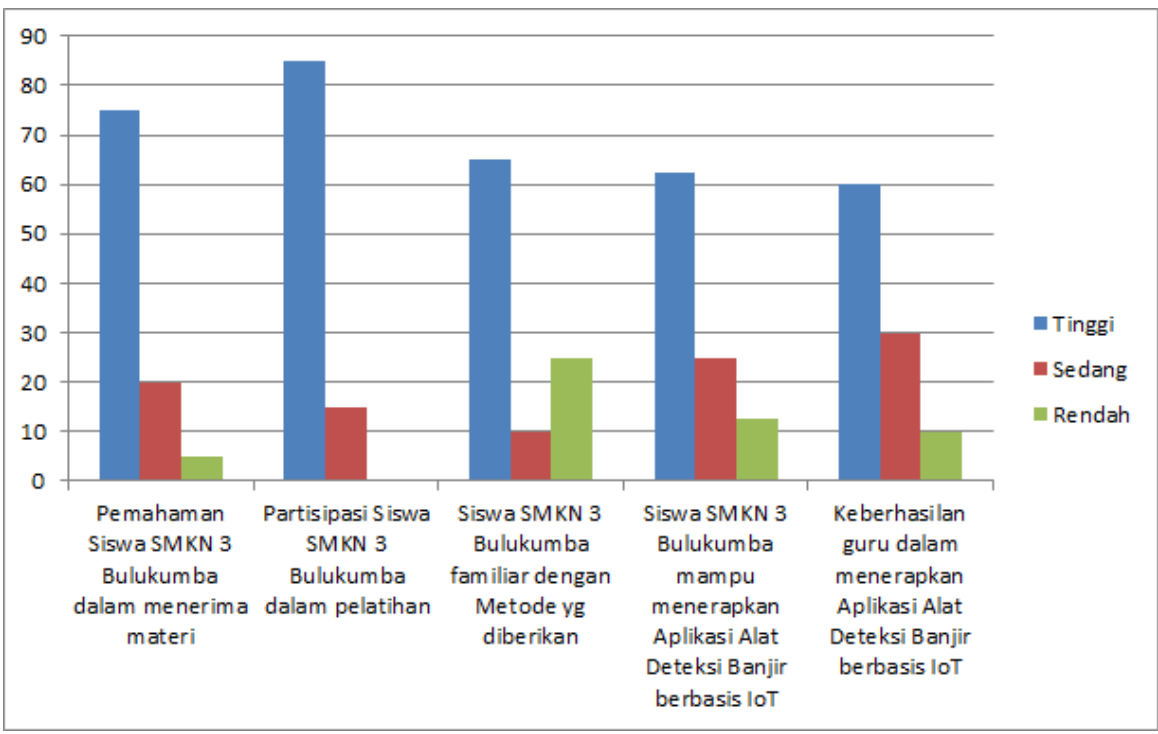

Gambar 1. Hasil penilaian keberhasilan pelatihan Siswa SMKN 3 Bulukumba

Pemahaman siswa SMKN 3 Bulukumba yang tinggi dalam menerima materi pelajaran sebesar $76 \%$, sedangkan pemahaman siswa SMKN 3 Bulukumba yang sedang dalam manerima materi pelatihan sebesar $16 \%$, dan pemahaman siswa SMKN 3 Bulukumba yang rendah dalam manerima materi pelajaran sebesar 8\%. Pada aspek ini pemahaman siswa SMKN 3 Bulukumba yang bervariasi disebabkan oleh karakteristik Siswa. Juga dipengaruhi oleh kemauan dan motivasi siswa SMKN 3 Bulukumba dalam menemukan sesuatu yang baru.
Partisipasi siswa SMKN 3 Bulukumba dalam pelatihan sangat tinggi, hal in terlihat pada Tabel $192 \%$ guru aktif dalam proses pelatihan. Partisipasi dapat dilihat dari aktifnya para siswa SMKN 3 Bulukumba mulai dari awal kegiatan pelatihan hingga pada penutupan kegiatan pelatihan. siswa SMKN 3 Bulukumba yang berhalangan dalam proses pelatihan diakibatkan oleh faktor eksternal yakni faktor keluarga. Keberhasilan guru dalam menerapkan aplikasi alat deteksi banjir berbasis IoT sebanyak 52\% berhasil, 32\% hampir berhasil dan $16 \%$ tidak berhasil. 


\section{KESIMPULAN}

Berdasarkan capaian hasil pelaksanaan pelatihan dan sosialisasi mitigasi bencana di SMKN 3 Bulukumba, maka dapat disimpulkan sebagai berikut:

1. Meningkatnya keterampilan dan pengetahuan siswa SMKN 3 Bulukumba terhadap pembuatan dan aplikasi teknologi informasi Deteksi banjir berbasis IoT.

2. Meningkatnya kesadaran siswa SMKN 3 Bulukumba akan menjaga lingkungan dari bahaya bencana banjir.

3. Meningkatnya pengetahuan siswa SMKN 3 Bulukumba tentang sikap tanggap bencana.

\section{DAFTAR PUSTAKA}

Anonim. 2016. Rencana Pembangunan Jangka Menengah Daerah Kabupaten Bulukumba Tahun 2016-2019.

RKPD BULUKUMBA. 2019. Kabupaten Bulukumba Pembangunan Daerah.

Arius,Dony.2008. Pengantar Ilmu Kriptografi Teori, Analisis, dan Implementasi. Skripsi Fakultas Teknik Universitas Negeri Yogyakarta.

Vina Salviana DS1 \& Dyah Erni Widyastuti. 2011. Pemberdayaan perempuan partisipatif integratif melalui model life skills. Humanity. Volume 6, Nomor 2, Maret 2011: $127-135$

Peraturan Pemerintah Nomor 21 Tahun 2008 tentang Penyelenggaraan Penanggulangan Bencana. Jakarta : Kementrian Hukum dan Hak Asasi Manusia.
Siswoko. 1985. Pola Pengendalian Banjir pada Sungai. Jakarta : Dirjen Pengairan, Departemen Pekerjaan Umum.

Wirawan, S.2002. Psikologi Lingkungan. Jakarta: PT Gramedia Widiasarana Indonesia.

https://mikroavr.com/pendeteksi-banjirgsm/ 